Western Washington University

Western CEDAR

\title{
Beyond Expectations: Effects of Early Elections in US Presidential Nomination Contests
}

Todd Donovan

Western Washington University, todd.donovan@wwu.edu

Rob Hunsaker

Follow this and additional works at: https://cedar.wwu.edu/politicalscience_facpubs

Part of the Political Science Commons

\section{Recommended Citation}

Donovan, Todd and Hunsaker, Rob, "Beyond Expectations: Effects of Early Elections in US Presidential Nomination Contests" (2009). Political Science Faculty Publications. 13.

https://cedar.wwu.edu/politicalscience_facpubs/13 


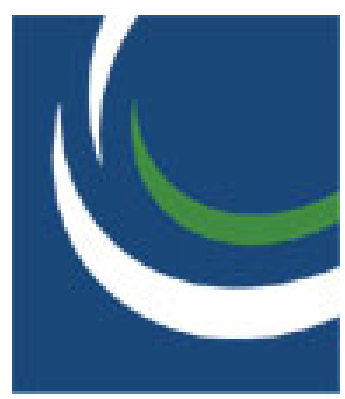

apsa

Beyond Expectations: Effects of Early Elections in U.S. Presidential Nomination Contests Author(s): Todd Donovan and Rob Hunsaker

Source: PS: Political Science and Politics, Vol. 42, No. 1 (Jan., 2009), pp. 45-52

Published by: American Political Science Association

Stable URL: http://www.jstor.org/stable/20452372

Accessed: 23/10/2014 17:31

Your use of the JSTOR archive indicates your acceptance of the Terms \& Conditions of Use, available at http://www.jstor.org/page/info/about/policies/terms.jsp

JSTOR is a not-for-profit service that helps scholars, researchers, and students discover, use, and build upon a wide range of content in a trusted digital archive. We use information technology and tools to increase productivity and facilitate new forms of scholarship. For more information about JSTOR, please contact support@ jstor.org.

American Political Science Association is collaborating with JSTOR to digitize, preserve and extend access to PS: Political Science and Politics. 


\section{Beyond Expectations: Effects of Early Elections in U.S. Presidential Nomination Contests}

Todd Donovan, Western Washington University

Rob Hunsaker, Western Washington University

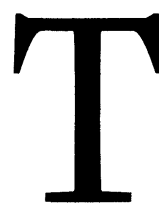

his article explores how results from Iowa may affect outcomes in subsequent nomination contests. We suggest that how Iowa matters may be determined, at least in part, by how voters and the news media assess whether or not candidates meet or exceed expectations there.

American presidential nomination contests are rather unique in that they make use of a sequential election process where voters participating in later contests have information about the results of earlier contests. Scholars recognize the potential effects that this sequential voting has on information used by voters (Morton and Williams 2001). These elections are also characterized by the fact that they are intrapartisan, or de facto non-partisan contests. Thus, voters select from a number of candidates within a party. This lowers the range of policy differentiation across candidates for voters to assess and removes major decision cues. Nomination contests with no incumbent remove the two dominant vote cues (party and incumbency) that voters regularly rely upon in candidate contests. In this regard, presidential nomination elections may be seen as a relatively low-information multi-candidate choice setting where voters must rely upon readily available cues ${ }^{1}$ when making decisions (e.g., Lupia 1994; McDermott 1997; 1998).

Furthermore, scholars have recognized that choices in presidential-nomination contests and other electoral settings may be affected by preferences for candidates (based either on policies or general likeability), but also by expectations about a candidate's chances of success. Voters and donors may assess candidates in terms of expectations about their prospects for winning the nomination, their prospects for being elected in November, or both (e.g., Abramowitz 1989; Abramson et al. 1992; Mutz 1995). There is also a rich, cross-national literature that provides systematic evidence of strategic or sophisticated voting in many multi-party (multi-candidate) choice settings (for a review see Cox 1997). For example, we have evidence from elections in Canada, Great Britain, New Zealand, Japan, and elsewhere that some voters may defect from their most preferred choice and vote for a lower-ranked option if they perceive their first option has little chance of winning (Cain 1978; Blais and Nadeau 1996; Karp et al. 2002).

One causal mechanism driving this is voter response to information about a candidate's electoral prospects. This can come in the form of information about a party's historic strength in an electoral district, information about candidate's standing in recent opinion polls, or other sources. Some voters are known to adjust vote intentions strategically in response to information from opinion polls (Johnston et al. 1992). Supporters of candidates or parties at the margins of viability may be particularly attentive to, and responsive to, information from opinion polls. In nomination elections voters also utilize information from early electoral events to adjust their voting intentions in response to changes in perceptions of viability (Abramson et al. 1992; Bartels 1985). ${ }^{2}$ Use of such information may be one process that generates momentum. Scholars are divided as to what momentum really is-whether it reflects learning or rational or irrational behavior (Mutz 1997; Bartels 1988; Brady and Johnston 1987). That said, the primary way of learning about candidate viability is likely to be the mass media.

\section{EARLY VOTING AND EXPECTATIONS}

These strands of literature allow us to understand how, and why, early election events have critical effects on the final outcomes in presidential nomination contests. Specifically, how (and why) do the Iowa caucuses and New Hampshire primary affect subsequent results in the nomination process, even when these two states play a trivial direct role in allocating convention delegates? Put differently, how do early events in small states contribute to candidate momentum in sequential nomination contests?

We propose a model of outcomes where early events matter, in part, because news about outcomes in these states serve as a major source of information about candidate viability in a relatively low-information choice setting. Early nomination events receive disproportionate media attention (relative to their share of delegates), and much of that media attention relates to expectations about a candidate's performance in early contests. The former claim here is uncontroversial, and the latter has been noted elsewhere (Brady and Johnston 1987). In this model, the role of the media can be seen as somewhat analogous to the process where share-market analysts set corporate earnings expectations. In share markets, when a firm exceeds its earnings expectations, its share price may rise. If it fails to meet expectations, its share price may fall. Likewise, more media attention may be earned by candidates who exceed expectations. Those who fall short of expectations may see their share of news coverage shrink. 
This model also grants the media substantial discretion in setting and adjusting expectations. Reporters, editors, and pundits define the criteria for determining whether a candidate scored an "easy win," managed an "upset," was "far behind," or suffered "defeat." There is substantial discretion in framing whether $25 \%$ is a "Comfortable Second" (Bill Clinton in New Hampshire in 1992), or 23\% is a "Strong Second" (Pat Buchanan in Iowa in 1992); or if $26 \%$ is a "Flat Tire" (Bob Dole in New Hampshire in 1996) or $26 \%$ is an "Overwhelming Defeat" (Howard Dean in New Hampshire in 2004). ${ }^{3}$

Horserace coverage of campaigns involves handicapping the candidate pool-with a substantial proportion of coverage focusing on who the frontrunners are expected to be, who the underdogs are, and who beats or fails to meet expectations. Initially, the decision to even report on one particular candidate rather than another, and the amount of attention granted, can be seen as the expression of media expectations. We can assume that candidates who are not expected to be players in a contest will receive less media attention-if for no other reason than media resources (column inches, minutes of news time, etc.) are finite. Attention must be rationed in favor of candidates who are expected to place relatively high.

Voters thus receive substantial information about the media's expectations of candidate viability, and of the media's interpretation of whether candidates met expectations, exceeded expectations, or failed to meet expectations. If some voters make choices on the basis of expectations about who is viable or electable, election results from early contests and subsequent changes in the media's treatment of candidates are likely to be a major source of readily available information for voters in later contests. Although this argument is not wholly original, few (if any) studies have estimated outcomes in U.S. presidential nomination contests as a sequential process that includes adjustments for media expectations associated with results from initial contests. ${ }^{4}$ Conventional accounts of outcomes in nomination contests emphasize the role of: (1) candidates' national opinion standings at the start of the process, (2) candidates' financial resources at the start, and (3) home-state advantages (Norrander 1993). Previous studies do not account for how the media sets its expectations, nor have many previous studies considered how alterations in the media's attention to a candidate because of an early outcome affect the candidate's prospects in subsequent contests.

\section{DATA}

Data from nomination contests from 1976 to 2008 are used to model initial press attention to candidates, candidate performance in Iowa and New Hampshire, and aggregate performance, respectively. These data include Gallup opinion measures of each candidate's national poll standing prior to the Iowa event, and measures of candidate fundraising in the year prior to the first nomination event (Iowa). Measures of national media attention to candidates include attention to candidates two weeks before and the days immediately after the Iowa caucus, and the week prior and immediate days after the New Hampshire primary. A total of 91 candidacies are in the dataset. Two incumbent presidents who had seri- ous primary challenges (Gerald Ford in 1976 and Jimmy Carter in 1980) are included, while other incumbents who lacked serious challenge (George H.W. Bush in 1992, Bill Clinton in 1996, and George W. Bush in 2004) are excluded.5

\section{MODELING EXPECTATIONS}

Given that we have no readily available measure of media expectations about front-running candidates, we make use of a relatively straightforward surrogate. Information about media expectations for each candidate is represented by the number of times a candidate's name appeared in New York Times stories about Iowa and New Hampshire that ran prior to voting in each state, and in stories that ran after voting. ${ }^{6}$ We coded mentions of the candidates' names in campaign related stories, while we omitted mentions of candidates in stories about governing. We assumed that candidates being mentioned most frequently across several stories were expected to be frontrunners.

Total attention to the Iowa and New Hampshire events is uneven across time. We measured media attention to individual candidates in a manner that is comparable across time by calculating the proportion of all candidate mentions of each Democrat and each Republican, respectively. Table 1 lists the top candidates on this measure based on New York Times stories that ran two weeks before Iowa, for both parties. Thus, Table 1 illustrates who received the most press attention prior to the Iowa caucuses, which we assume to reflect initial (preIowa) media expectations of candidate viability.

We also calculate how media attention to these candidates shifted in the days immediately after Iowa and New Hampshire, respectively, by comparing initial press attention prior to voting to attention in articles after results were known. Table 2 lists the candidates with the largest net changes by how often they were mentioned in stories about Iowa before the vote, and then after. Table 3 lists the same information for New Hampshire. For example, Pat Robertson was mentioned quite infrequently in stories about Iowa prior to the 1988 vote, but his proportionate share of references to all GOP candidates increased by 21 percentage points (from just $10 \%$ to $31 \%$ ) in stories about Iowa published in the days immediately after his second-place finish.

This measure of change in media attention serves as a surrogate measure of how media expectations of candidate viability adjust after Iowa votes. Prior to the result of the 1988 Iowa caucus, expectations (and attention) for Dole, Bush, and Kemp were higher; after Iowa caucused, expectations about Robertson shifted, and he enjoyed greater media attention prior to New Hampshire. As another example, Gary Hart received relatively little notice prior to Iowa $(10 \%$ of Democratic candidate mentions in 1984). However, after posting a surprising second-place finish in Iowa (with just 16\%, 32 points behind Walter Mondale), his share of media attention in postresult coverage of Iowa more than doubled (increasing from $9 \%$ to $19 \%$ overall), while Mondale's share of press attention declined relative to that given his rivals. Hart's 1984 victory in New Hampshire corresponded with another $27 \%$ bounce in attention; Buchanan enjoyed a similar phenomenon after collecting a mere 22,000 Iowa caucus votes in a surprise 


\section{Table 1}

Most Frequently Mentioned Candidates in Iowa Stories (Pre-caucus)

\begin{tabular}{|c|c|c|c|c|}
\hline & \multicolumn{2}{|c|}{ DEMOCRAT } & \multicolumn{2}{|c|}{ REPUBLICAN } \\
\hline \multirow[t]{3}{*}{1976} & Carter & $(.24)$ & Reagan & (.52) \\
\hline & Bayh & (.16) & Ford & (.48) \\
\hline & Udall & $(.10)$ & & \\
\hline \multirow[t]{3}{*}{1980} & Carter & $(.60)$ & Regan & (.34) \\
\hline & Kennedy & $(.30)$ & Bush & $(.31)$ \\
\hline & & & Connelly & (.11) \\
\hline \multirow[t]{3}{*}{1984} & Mondale & (.43) & $\mathrm{n} / \mathrm{a}$ & \\
\hline & Glenn & $(.20)$ & & \\
\hline & Askew & $(.10)$ & & \\
\hline \multirow[t]{3}{*}{1988} & Gephardt & $(.31)$ & Dole & (.42) \\
\hline & Dukakis & $(.21)$ & Bush & (.27) \\
\hline & Simon & (.19) & Kemp & $(.15)$ \\
\hline \multirow[t]{2}{*}{1992} & Harkin & $(.71)$ & $n / a$ & \\
\hline & Clinton & $(.11)$ & & \\
\hline \multirow[t]{3}{*}{1996} & $\mathrm{n} / \mathrm{a}$ & & Forbes & (.40) \\
\hline & & & Dole & $(.22)$ \\
\hline & & & Gramm & (.13) \\
\hline \multirow[t]{3}{*}{2000} & Bradley & $(.54)$ & Bush & (.55) \\
\hline & Gore & $(.46)$ & Forbes & (.22) \\
\hline & & & McCain & (.15) \\
\hline \multirow[t]{3}{*}{2004} & Dean & $(.47)$ & $n / a$ & \\
\hline & Gephardt & $(.19)$ & & \\
\hline & Kerry & (.14) & & \\
\hline \multirow[t]{3}{*}{2008} & Edwards & $(.33)$ & Romney & $(.36)$ \\
\hline & Obama & (.28) & Huckabee & (.29) \\
\hline & Clinton & $(.28)$ & McCain & (.15) \\
\hline
\end{tabular}

Note: Cell entries are the candidate's proportionate share of all candidate mentions, per party.

second-place finish in 1996. In terms of beating initial media expectations, Hart $(1984,37 \%)$, Reagan (1976, 36\%), B. Clinton (1992, 35\%), Buchanan (1996, 28\%), Tsongas (1992, 23\%), Carter (1976, 20\%), Huckabee (2008, 19\%), H. Clinton (2008, $18 \%)$, Gore (2000, 17\%), Kerry (2004, 17\%), Robertson (1988, $17 \%)$, and Obama $(2008,16 \%)$ rank highest in the net gain in attention from before Iowa to immediately after New Hampshire.?

How then, are initial media expectations set, and how might they predict voting in early events? More important, how do changes in expectations produced by the Iowa results affect voting in a subsequent nominating event (New Hampshire)? ${ }^{8}$ Conventional wisdom and logic suggest several factors that drive the press to give some candidates more early attention: fundraising, poll standing, incumbency, ${ }^{9}$ and home-state
Table 2

Largest Change in Press Attention to Candidate: 1976-2008; Before and After the Iowa Caucus

\begin{tabular}{ll|lr} 
BIGGEST GAIN & & BIGGEST LOSS & \\
\hline Baker, 1980 & $+7 \%$ & Mondale, 1984 & $-7 \%$ \\
\hline Gephardt, 1988 & $+7 \%$ & McCain, 2008 & $-8 \%$ \\
\hline Forbes, 2000 & $+8 \%$ & McCain, 2000 & $-8 \%$ \\
\hline Harris, 1976 & $+9 \%$ & Kemp, 1988 & $-8 \%$ \\
\hline Kerry, 2004 & $+9 \%$ & Dole, 1988 & $-8 \%$ \\
\hline H. Clinton, 2008 & $+9 \%$ & Gephardt, 2004 & $-8 \%$ \\
\hline Keyes, 2000 & $+9 \%$ & McCain, 2008 & $-8 \%$ \\
\hline Hart, 1984 & $+10 \%$ & Humphrey, 1976 & $-9 \%$ \\
\hline Reagan, 1976 & $+12 \%$ & G. H.W. Bush, 1988 & $-9 \%$ \\
\hline Tsongas, 1992 & $+15 \%$ & Gephart, 2004 & $-10 \%$ \\
\hline Buchanan, 1996 & $+17 \%$ & Ford 1976 & $-12 \%$ \\
\hline Obama, 2008 & $+17 \%$ & G. W. Bush, 2000 & $-18 \%$ \\
\hline Robertson 1988 & $+21 \%$ & Forbes, 1996 & $-19 \%$ \\
\hline Huckabee, 2008 & $+21 \%$ & Edwards, 2008 & $-21 \%$ \\
\hline B. Clinton, 1992 & $+24 \%$ & Harkin, 1992 & $-39 \%$ \\
\hline
\end{tabular}

Table 3

Largest Change in Press Attention to Candidate: 1976-2008; Before and After the New Hampshire Primary.

\begin{tabular}{ll|lr} 
BIGGEST GAIN & & BIGGEST LOSS & \\
\hline H. Clinton, 2008 & $+8 \%$ & Brown, 1980 & $-7 \%$ \\
\hline Kerry, 2004 & $+8 \%$ & Harkin, 1992 & $-7 \%$ \\
\hline Udall, 1976 & $+8 \%$ & Kennedy, 1980 & $-8 \%$ \\
\hline Dole, 1988 & $+9 \%$ & McCain, 2008 & $-9 \%$ \\
\hline G. W. Bush, 2000 & $+9 \%$ & Bush, 1992 & $-9 \%$ \\
\hline Buchanan, 1992 & $+9 \%$ & Gephardt, 1988 & $-9 \%$ \\
\hline Gore, 2000 & $+10 \%$ & Clark, 2004 & $-9 \%$ \\
\hline Buchanan, 1996 & $+11 \%$ & Forbes, 1996 & $-9 \%$ \\
\hline B. Clinton, 1992 & $+11 \%$ & Glenn, 1984 & $-10 \%$ \\
\hline Paul, 2008 & $+12 \%$ & Bradley, 2000 & $-10 \%$ \\
\hline Carter, 1976 & $+16 \%$ & B. Kerry, 1992 & $-11 \%$ \\
\hline Carter, 1980 & $+16 \%$ & J. Jackson, 1984 & $-12 \%$ \\
\hline Reagan, 1980 & $+17 \%$ & Shriver, 1976 & $-12 \%$ \\
\hline McCain, 2000 & $+19 \%$ & Simon, 1988 & $-12 \%$ \\
\hline Reagan, 1976 & $+24 \%$ & Forbes, 2000 & $-21 \%$ \\
\hline Hart, 1984 & $+27 \%$ & Ford, 1976 & $-24 \%$ \\
\hline
\end{tabular}

Note: Percent change in candidate's share of references among candidates from the same party. 


\begin{tabular}{|c|c|}
\hline $\begin{array}{l}\text { Estimates of Media A } \\
\text { Candidates 1976-200 }\end{array}$ & $\begin{array}{l}\text { Iowa } \\
\text { us }\end{array}$ \\
\hline Pre-lowa National poll \% & .56 \\
\hline (Gallup) & (.09) \\
\hline Fundraising (millions of $\$$ ) & .22 \\
\hline & $(.08)$ \\
\hline Incumbent & 22.9 \\
\hline & (10.9) \\
\hline Home State (Harkin) & 69.6 \\
\hline & (10.9) \\
\hline Constant & -.38 \\
\hline & (3.4) \\
\hline$R^{2}=$ & .68 \\
\hline Adjusted $R^{2}=$ & .63 \\
\hline$N=91$ & \\
\hline $\begin{array}{l}\text { Note: Dependent variable equals percent } \\
\text { coefficients reported, with errors in paren } \\
\text { mies for 1976, 1980, 1984, 1988, 1992, } 19 \\
\text { not reported). }\end{array}$ & $\begin{array}{l}\text { candidate. OLS } \\
\text { stimated with dun } \\
\text { (coefficients }\end{array}$ \\
\hline
\end{tabular}

advantages. ${ }^{10}$ We expect candidates who raised more money prior to Iowa, those with higher national poll standings, those from Iowa, and incumbents to receive more initial media attention. We measured campaign fundraising as total funds raised the year prior to Iowa in terms of inflation-adjusted (to 2000) dollars. These factors are used to estimate a candidate's share (proportionately) of total news mentions of candidate names prior to Iowa. Although some of these items are well correlated, the correlations are by no means perfect. ${ }^{11}$

Table 4 reports results of estimates of candidate share of press attention in the weeks before Iowa. We find that about $70 \%$ of variance in candidate share of press attention (our surrogate for expectations) can be explained by fundraising, poll standing, and the two candidate-specific factors. Each additional $10 \%$ in opinion standing is associated with $5 \%$ greater media attention, and $\$ 10$ million adds an additional $4.8 \%$ share. These results are not surprising, but they do illustrate that money and poll numbers are not perfect predictors of media attention. Part of press coverage likely involves setting expectations by interpreting if a less-known but well-financed candidate is deserving of as much attention as a well-known officeholder. Indeed, these nomination contests are frequented by well-financed candidates who gain little traction with voters (John Connelly, \$19 million in 1980; John Glenn, \$11 million in 1984; Phil Gramm, \$22.3 million in 1996; Rudy Giuliani, $\$ 51$ million in 2008) and well-financed candidates who were relatively unknown quantities early on (Robertson, \$24 million in 1998; Steve Forbes, \$20 million in 1996; Mitt Romney, $\$ 74$ million in 2008). ${ }^{12}$ What then are the potential effects of media attention/expectations, independent of candidate poll standing and fundraising? Or, forgetting pretense to causal arguments, does media attention predict something that fundraising and poll standing might not?

Table 5 reports estimates of Iowa caucus results from 1976 2008, using the standard variables included in models estimating nomination outcomes (Norrander 1993; Mayer 1996; 2003). When standard forecasting variables are used (column 1), money and poll standing appear to have substantial power to predict results in Iowa. In contrast, when press attention to candidates is used to estimate results, the effects of money are eliminated, and the effects of poll standing disappeared (when vote percent is modeled-but not when place of candidate finish is estimated). The Iowa vote share is also estimated here with an instrumental variable, where press attention predicted from the model reported in Table 4 is used to predict the Iowa vote share. Again, we see that press coverage of a
Table 5

\section{Estimating Iowa Caucus Results, 1976-2008}

\begin{tabular}{|c|c|c|c|c|c|c|}
\hline \multirow[b]{2}{*}{ Pre-lowa Media Attention } & \multicolumn{4}{|c|}{ VOTE PERCENT } & \multicolumn{2}{|c|}{ PLACE $(1 \text { st }=1)^{*}$} \\
\hline & - & $\begin{array}{l}.76 \\
(.09)\end{array}$ & $\begin{array}{l}.79 \\
(.06)\end{array}$ & - & - & $\begin{array}{l}-.11 \\
(.02)\end{array}$ \\
\hline $\begin{array}{l}\text { Predicted Pre-lowa Attention } \\
\text { (instrument from Table 4)+ }\end{array}$ & - & - & - & $\begin{array}{r}.79 \\
(.12) \\
\end{array}$ & - & - \\
\hline $\begin{array}{l}\text { Pre-lowa National Poll \% } \\
\text { (Gallup) }\end{array}$ & $\begin{array}{r}.49 \\
(.10)\end{array}$ & $\begin{array}{r}.06 \\
(.09)\end{array}$ & - & - & $\begin{array}{l}-.05 \\
(.02)\end{array}$ & $\begin{array}{l}.01 \\
(.02)\end{array}$ \\
\hline Fundraising (millions of \$) & $\begin{array}{c}.16 \\
(.10)\end{array}$ & $\begin{array}{l}-.01 \\
(.07)\end{array}$ & - & - & $\begin{array}{l}-.03 \\
(.02)\end{array}$ & $\begin{array}{r}-.007 \\
(.03)\end{array}$ \\
\hline Home State lowa & $\begin{array}{r}77.5 \\
(12.3)\end{array}$ & $\begin{array}{l}24.9 \\
(11.4)\end{array}$ & $\begin{array}{r}22.5 \\
(9.7)\end{array}$ & $\begin{array}{c}27.2 \\
(14.4)\end{array}$ & $\begin{array}{l}-3.5 \\
(2.0)\end{array}$ & $\begin{array}{r}4.3 \\
(2.0)\end{array}$ \\
\hline Incumbent President. & $\begin{array}{l}25.7 \\
(12.4)\end{array}$ & $\begin{array}{l}8.4 \\
(9.5)\end{array}$ & $\begin{array}{r}9.2 \\
(9.0)\end{array}$ & $\begin{array}{l}7.4 \\
(13)\end{array}$ & $\begin{array}{l}-1.2 \\
(2.0)\end{array}$ & $\begin{array}{c}1.4 \\
(1.7)\end{array}$ \\
\hline Constant & $\begin{array}{l}2.3 \\
(3.8)\end{array}$ & $\begin{array}{c}2.6 \\
(2.8)\end{array}$ & $\begin{array}{c}1.4 \\
(1.8)\end{array}$ & $\begin{array}{r}0.9 \\
(4.4)\end{array}$ & $\begin{array}{l}5.8 \\
(.64)\end{array}$ & $\begin{array}{l}5.7 \\
(.52)\end{array}$ \\
\hline $\mathrm{R}^{2}$ & .60 & .78 & .77 & .61 & .35 & .59 \\
\hline Adjusted $\mathrm{R}^{2}$ & .53 & .74 & .75 & .55 & .25 & .51 \\
\hline $\mathrm{N}$ & 91 & 91 & 91 & 76 & 91 & 91 \\
\hline
\end{tabular}

Note: OLS estimates reported. All models estimated with dummies for 1976, 1980, 1984, 1988, 1992, 1996, 2000, and 2008 (coefficients not reported).

+Instrument generated from Table 4, without dummies for year.

*Same substantive results with ordered probit. 
candidate (predicted by the candidates' fundraising and polling numbers) outperforms models that use only polling and finance to predict outcomes in Iowa. How should these results be interpreted? Why would media attention better predict (or predict as adequately) as the direct measures of money and poll status?

Clearly, media attention to candidates covaries with fundraising, and there is no way to clearly sort out the alternate causal processes that may be at work here. Reporters and editors may be particularly savvy at using information beyond poll numbers to anticipating who will succeed in Iowa, and thus direct more of their attention to those candidates. That said, these results are consistent with a process where candidates who receive more media attention gain an electoral advantage beyond that associated with their fundraising and national standing in opinion polls.

Iowa's potential effects on nomination contests in subsequent states are a more important matter. As good as reporters, editors, and pundits may be at anticipating outcomes in Iowa, they often find their initial expectations were off. One of the primary political functions of the news media is interpreting and framing events-that is-defining the meaning of such things as victory, second place, or 26\%. Expectations are then adjusted, with increased attention directed at candidates who exceeded initial expectations (Hart in 1984; Robertson in 1988; Buchanan in 1996; Kerry in 2004) or were not expected to do well anyway (Bill Clinton and Paul Tsongas in 1992). Table 6 reports estimates of the New Hampshire primary results from 1976 to 2008. Candidate vote shares (and places) are estimated as a function of the standard variables (early poll standing, finances, state of residence), with two independent variables representing the potential effects of Iowa: the candidate's vote share in Iowa and the change in media attention directed at the candidate immediately after Iowa. ${ }^{13}$ Again, the underlying assumption here is that some voters opt for candidates they expect to be more viable, and that they make use of election results, and the media's interpretation of results, to assess viability.

Results in Table 6, albeit estimated with aggregate data, are consistent with such a process. We see a robust association between a candidate's performance in Iowa and New Hampshire. The Iowa vote share, and the Iowa place of finish (not shown), are significant predictors of the New Hampshire vote share, the likelihood of winning in New Hampshire, and the place of finish in New Hampshire. This result holds when we control for the candidate's fundraising and initial standing in national polls. Independent of these effects, we also see that change in media attention toward a candidate post-Iowa also has a significant relationship with support in New Hampshire. Candidates like Hart, Robertson, Buchanan, and Kerry may have had an additional edge in New Hampshire because of the shift in media attention they earned from their surprise finishes in
Iowa. Although there is no relationship between the shift in media attention toward a candidate and winning New Hampshire, the potential importance of the media bounce coming out of Iowa on the overall nomination contest should not be underestimated.

As Table 7 shows, performance in New Hampshire is a strong predictor of the aggregate primary vote (and thus delegate share), with Iowa having a more muted effect (depending on specification). But results in Table 7 demonstrate that change in media attention after Iowa, and after New Hampshire, have important substantive effects on how much support a candidate receives throughout the nomination contest. Increased attention to a candidate immediately after Iowa, and immediately after New Hampshire, has a significant relationship with increased vote share across the nomination contests. When Table 5 and Table 6 are considered together, the results suggest that changes in news about candidates due to results in Iowa affect how well a candidate does in New Hampshire. Candidate performance in New Hampshire then produces additional adjustments in media attention to candidates (and expectations about viability), and this is associated with how well a candidate fares overall. One need not win Iowa to win New Hampshire, nor must one win New Hampshire to win a nomination (although it clearly helps). However, additive models in Table 7 suggest performance in Iowa had less effect on overall primary vote share than performance in New Hampshire did; but it is important to remember that the 


\begin{tabular}{|c|c|c|c|c|}
\hline \multirow[b]{2}{*}{$\begin{array}{l}\text { Pre-lowa Poll Standing } \\
\text { (Gallup \%) }\end{array}$} & \multicolumn{3}{|c|}{ VOTE SHARE } & \multirow{2}{*}{$\begin{array}{c}\begin{array}{c}\text { WON } \\
\text { NOMINATION?* }\end{array} \\
.08 \\
(.04)\end{array}$} \\
\hline & $\begin{array}{r}.61 \\
(.11)\end{array}$ & $\begin{array}{l}.71 \\
(.10)\end{array}$ & $\begin{array}{r}.68 \\
(.11)\end{array}$ & \\
\hline Fundraising (millions of \$) & $\begin{array}{l}-.01 \\
(.17)\end{array}$ & $\begin{array}{l}.06 \\
(.15)\end{array}$ & $\begin{array}{r}.05 \\
(.15)\end{array}$ & $\begin{array}{l}.02 \\
(.05)\end{array}$ \\
\hline lowa Vote \% & $\begin{array}{l}.11 \\
(.10)\end{array}$ & $\begin{array}{l}.20 \\
(.08)\end{array}$ & $\begin{array}{l}.17 \\
(.09)\end{array}$ & $\begin{array}{l}.03 \\
(.05)\end{array}$ \\
\hline $\begin{array}{l}\text { \% Change in Media } \\
\text { Post-lowa }\end{array}$ & $\begin{array}{l}.29 \\
(.15)\end{array}$ & $\begin{array}{l}.42 \\
(.12)\end{array}$ & $\begin{array}{r}.39 \\
(.13)\end{array}$ & $\begin{array}{l}.05 \\
(.06)\end{array}$ \\
\hline New Hampshire Vote \% & $\begin{array}{l}.51 \\
(.13)\end{array}$ & - & $\begin{array}{l}.11 \\
(.15)\end{array}$ & $\begin{array}{l}.06 \\
(.05)\end{array}$ \\
\hline Won New Hampshire? & - & $\begin{array}{l}21.5 \\
(3.5)\end{array}$ & $\begin{array}{l}19.5 \\
(4.5)\end{array}$ & - \\
\hline $\begin{array}{l}\% \text { Change in Media } \\
\text { Post-New Hampshire }\end{array}$ & $\begin{array}{l}.35 \\
(.14)\end{array}$ & $\begin{array}{r}.25 \\
(.13)\end{array}$ & $\begin{array}{r}.25 \\
(.13)\end{array}$ & $\begin{array}{l}.01 \\
(.04)\end{array}$ \\
\hline Constant & $\begin{array}{l}-1.0 \\
(4.1)\end{array}$ & $\begin{array}{l}-0.6 \\
(3.6)\end{array}$ & $\begin{array}{l}-0.9 \\
(3.6)\end{array}$ & $\begin{array}{l}-6.0 \\
(1.6)\end{array}$ \\
\hline $\mathrm{R}^{2}$ & .79 & .84 & .84 & \\
\hline Adjusted $R^{2}$ & .75 & .81 & .81 & \\
\hline Pseudo $\mathrm{R}^{2}$ & & & & .60 \\
\hline $\mathrm{N}$ & 76 & 76 & 76 & 76 \\
\hline
\end{tabular}

nomination process is sequential. Success in New Hampshire corresponds with earlier electoral success in Iowa and the media bounce associated with beating expectations in Iowa. Beating early expectations may determine whether a candidacy ends quickly or whether it lasts longer.

We also produced estimates from the first model in Table 7 using data from the 1976-2004 elections (omitting 2008) in order to test how the model predicted the 2008 outcomes. These predictions are listed in Table 8 . Table 8 illustrates that the model performs fairly well in predicting the overall vote share for the main candidates, although it under predicts Obama's and McCain's vote share. Of course, vote share is not the same as winning the nomination. Results in Table 7, and the predictions in Table 8, suggest that a model based on preIowa poll standing, results from the earliest contests, and shifting media attention do a good job explaining a candidate's vote share (which corresponds highly with how long a candidate remains in the contest). These results also demonstrate that such models have less utility in distinguishing which candidates actually win.

Nomination contests are sequential. This sets the stage for early events to have important effects that cascade over time. Early results can alter media assessments of a candidate's via- bility, with the change in news attention breathing new life into some candidacies while leaving others all but forgotten. From 1976-2008, media expectations about which candidates were viable were set before Iowa voted. Iowa's results then led to altered media expectations about who the frontrunners were. New Hampshire results further altered media expectations about candidate viability, and these shifts in press attention to candidates then shaped the context voters faced in subsequent states.

\section{DISCUSSION AND IMPLICATIONS}

This presents an important question, then, about the role of the media in setting and shifting expectations about candidate viability. The analogy here between share market analysts and the media is obviously imperfect. In the market, the analyst sets expectations, and the market responds. In this election context, we assume the media sets its own expectations and then voters and the media responds to how candidate performance matches expectations. But where share-market analysts face repercussions if their analyses are flawed (i.e., their clients suffer financial loss), there is no such mechanism policing the accuracy of media analysis. News media have substantial discretion in defining who is viable, and there are no strong incentives for the press to set expectations correctly (if that were even possible).

News-media interpretation of whether the same number of votes is a comfortable second place for one candidate or a crushing defeat for another, or whether being a U.S. senator from a nearby state should be used to discount the importance of support for one candidate in New Hampshire (e.g., Paul Tsongas in 1992) but not another (e.g., John Kerry in 2004), may combine with interpretation of random moments in early

\begin{tabular}{|c|c|c|}
\hline & ACTUAL & PREDICTED \\
\hline \multicolumn{3}{|l|}{ Republicans } \\
\hline McCain & 47.2 & 41.5 \\
\hline Huckabee & 20.1 & 25.3 \\
\hline Romney & 21.7 & 23.4 \\
\hline Giuliani & 2.8 & 12.1 \\
\hline \multicolumn{3}{|l|}{ Democrats } \\
\hline Obama & 48.3 & 42.6 \\
\hline Clinton & 47.1 & 47.4 \\
\hline Edwards & 2.7 & 8.6 \\
\hline
\end{tabular}


states to amplify the effects that these early states have by altering mass perceptions of candidate viability in subsequent states. Models reported in this paper cannot account for such effects. But as an extreme example of an Iowa event having effects in New Hampshire, and on the eventual nomination outcome, consider Howard Dean's 2004 caucus-night speech in Iowa. The information flow from Iowa to New Hampshire was not simply that Dean placed third and failed to meet expectations and that Kerry became more viable (and received more attention). A CNN poll conducted prior to the New Hampshire primary estimated that $90 \%$ of respondents in New Hampshire saw or heard the speech before they voted; $48 \%$ saw or heard it at least six times, with many saying they saw or heard it at least a dozen times. ${ }^{14}$ Events such as Dean's "scream," Muskie's "crying," Reagan's "I paid for this microphone," or Bill and Hillary Clinton being anointed "comeback kids" in New Hampshire combine with interpretation of objective outcomes to affect which candidates remain (or become more) viable to voters in the remaining contests.

In short, the sequential nomination process places substantial discretion with the news. The media's response to margins of a handful of votes in early states-and interpretation about whether someone exceeded expectations based on narrow margins-may be enough to leave a better-financed (or simply better) candidate stuck in third place with no perception of viability. Consider the fate of Lamar Alexander, and the media bounce that culture warrior Pat Buchanan enjoyed after Iowa in 1996. It is possible that Buchanan was unelectable. Yet Buchanan beat Alexander by a scant 5,000 votes to secure a surprise second place in Iowa. The media boost associated with that may have helped Buchanan beat Dole (by a mere 2,000 votes) and Alexander (by 9,000 votes, $18 \%$ to $23 \%$ ) in New Hampshire. A few thousand votes in Iowa was the difference between a headline-grabbing second versus a curious third-place finish for Buchanan, and it may have doomed Alexander. Increased media attention after Iowa propelled Buchanan to New Hampshire, and New Hampshire drove media attention away from Alexander.

Or consider the fate of Wesley Clark's candidacy in 2004. Clark opted to ignore Iowa. He placed third in New Hampshire on January 27, just ahead of Edwards (and behind Dean and Kerry). The next nomination event deemed most worthy of reporting on was the South Carolina primary on February 3 . Edwards, being born there, was expected to do well, and he did, winning $45 \%$ to $30 \%$ over Kerry. That was Edwards's only win in the seven contests conducted that day, along with two second-place finishes. Clark won one (Oklahoma), placed second in three states (Arizona, New Mexico, and North Dakota), and beat Edwards in most February 3 states. Yet media attention to Clark had already began to wane immediately after New Hampshire. Despite beating Edwards in New Hampshire, and on February 3, the news media focus was on South Carolina, and on Edwards. In 2004 and other years, news expectations were based on Iowa, New Hampshire, and South Carolina-not New Mexico, Oklahoma, and Arizona. Clark didn't contest Iowa, and he did well in the wrong states, in the wrong time zones. The disproportionate attention directed at South Carolina in 2004, and the effects it may have had on voter perceptions of candidate viability, was driven by media discretion, not by party rules.

It is probably impossible to say what the "correct" news stories about expectations and candidate viability should have been in these cases, or what they should be in any year. The point is that outcomes in early contests generate information about viability in the form of press attention granted to some candidates and attention denied to others. The American news media does not have consistent criteria for determining how outcomes in early contests should be interpreted. Iowa is particularly problematic. Iowa has an arcane and non-transparent caucus process that, as a result of non-transparency, may increase media influence over the flow of information about candidate viability. The lack of transparency facilitates discretion in interpretation of events, and may further amplify the effect media has (unintentionally or not) on changing the course of elections by affecting perceptions of candidate viability on the basis of a very small number of votes.

A two-candidate contest between an alleged frontrunner and a surprising opponent is a hard story for reporters, editors, and producers to resist because it is an easy story. It is easy, and more exciting, to report that a candidate had a surprise second place or that someone failed to meet expectations than to explain how Iowa actually works. The reality of Iowa-for Democrats at least-is that actual voter support for candidates is not reported and the statewide apportionment of precinct-level delegates has everything to do with general election results from previous years and nothing to do with how many people show up to vote at the precinct nominating caucuses. There is a weak link between the aggregate support a candidate receives across all the precinct caucuses and the delegate totals elected to the county level that media outlets use to report how a candidate placed. In a close contest, it is possible that a candidate who mobilizes new voters and/or has strong support in certain areas will receive the most firstpreference votes across all precincts but place second or third in the tally of delegates selected for the county conventions. ${ }^{15}$ But there must be a story, and in it, someone must win, place, and show; and the story will likely be that someone met, exceeded, or failed to meet media expectations.

\section{NOTES}

1. In ballot-measure voting, cues may be endorsements and information about proponents and opponents of a measure. Race, gender, and association with salient politician and social groups may also serve as cues in candidate contests.

2. Bartels (1985) demonstrates that candidate preferences are strongly projected onto expectations, so the relationship is reciprocal, and that the effects of expectations depend on whether a contest is close or not.

3. These phrases are taken from New York Times headlines. Dean's $26 \%$ "Overwhelming Defeat" was a second-place showing in New Hampshire, $12 \%$ behind Kerry in 2004. Clinton's $25 \%$ "comfortable second" was $8 \%$ behind Paul Tsongas in 1992.

4. Morton and Williams (2001) employ laboratory experiments to test their hypotheses about simultaneous vs. sequential elections. Many previous forecasting models estimate aggregate primary vote share or nomination outcome as a simultaneous election either with (Adkins and Dowdle 2001) or without (Mayer 1996; 2003) accounting New Hampshire as part of an additive model, and most omit Iowa.

5. Substantive results are unaffected when sitting presidents are omitted. 
6. Double counting of stories was avoided by coding post-Iowa stories with Iowa bylines or headlines as Iowa content, and pre-New Hampshire stories with New Hampshire bylines and/or headlines as New Hampshire content.

7. The value for $\mathrm{B}$. Clinton is inflated by limited initial attention to Iowa that largely focused on Tom Harkin. Harkin had the largest decline in share of press attention $(-47 \%)$, followed by Ford $(1976,-36 \%)$, Edwards (2008, -28\%), Forbes (1996, -27\%), and Bradley (2000, -17\%).

8. There is clearly a causal morass in arguing that initial press attention simply reflects expectations that are unique from pure reporting of re sults. The two are highly correlated. However change in media attention from pre-Iowa to post-Iowa coverage is not well correlated with the Iowa from pre-lowa to post-lowa coverage is not well correlated with the low
vote $(r=-0.22)$, and change in attention is inversely correlated with initial Iowa attention $(-0.41)$.

9. Ford in 1976; Carter in 1980.

10. This is limited to Tom Harkin of Iowa, who ran in 1992.

11. The correlation between proportion of mentions and poll strength is 0.68 ; mentions and money is 0.53 ; the correlation between money and poll strength is 0.58 .

12. Values here converted to year 2000 dollars.

13. Recall that these variables are not well correlated with each other.

14. www.usatoday.com/news/polls/tables/live/2004-01-25-poll-results.htm

15. A related phenomenon occurred in the 2008 Nevada precinct caucuses, where Clinton beat Obama $50 \%$ to $45 \%$ in a tally of the 10,740 delegates elected by 117,600 voters to 17 county conventions. The geographic distrielected by 117,600 voters to 17 county conventions. The geographic distri-
bution of support across counties led the state party to acknowledge that Obama would receive more national convention delegates than Clinton. As in Iowa, actual preferences of the 117,000 voters were not reported by the party. Most outlets reported the state as a Clinton victory.

\section{REFERENCES}

Abramowitz, Alan. 1989. "Viability, Electability, and Candidate Choice in a Presidential Primary Election: A Test of Competing Models." Journal of Politics 51: 977-92.

Abramson, Paul, John Aldrich, Phil Paolino, and David Rhode. 1992. "Sophisticated Voting in the 1988 Presidential Primaries." American Political Science Review 86 (March): 55-69

Adkins, Randall, and Andrew Dowdle. 2001. "How Important Are Iowa and New Hampshire to Winning Post-Reform Presidential Nominations?" Political Research Quarterly 54: 431-44.

Bartels, Larry. 1985. "Expectations and Preferences in Presidential Nominating Campaigns." American Political Science Review 79 (September): 804-15.
1988. Presidential Primaries and the Dynamics of Voter Choice. Princeton: Princeton University Press.

Blais, Andre, and Richard Nadeau. 1996. "Measuring Strategic Voting: a Twostep Procedure." Electoral Studies 15: 39-52.

Brady, Henry E., and Richard Johnston. 1987. "What's the Primary Message: Horse Race or Issue Journalism?" In Media and Momentum, ed. G. Orren and Nelson Polsby. Chatham, NJ: Chatham House.

Cain, Bruce. 1978. "Strategic Voting in Britain." American Journal of Political Science 22: 639-55.

Cox, Gary. 1997. Making Votes Count: Strategic Coordination in the World's Elec toral Systems. Cambridge: Cambridge University Press.

Johnston, Richard, Andre Blais, Henry E. Brady, and Jean Crete. 1992. Letting the People Decide: Dynamics of a Canadian Election. Stanford, CA: Stanford University Press.

Karp, Jeffery, Jack Vowles, Susan Banducci, and Todd Donovan. 2002. "Strategic Voting, Party Activity, and Candidate Effects: Testing Explanations for Split Voting in New Zealand's New Mixed System." Electoral Studies 21: Split Voti.

Lupia, Arthur. 1994. "Shortcuts versus Encyclopedias." American Political Science Review 88 (March): 63-76.

Mayer, William G. 1996. "Forecasting Presidential Nominations." In In Pursuit of the White House: How We Choose Our Presidential Nominees, ed. William G. Mayer. Chatham, NJ: Chatham House, 44-71.

_ 2003. "Forecasting Presidential Nominations, or My Model Worked Just Fine, Thank You." PS: Political Science \& Politics 36 (April): 153-57.

McDermott, Monika L. 1997. "Voting Cues in Low-Information Elections: Candidate Gender as a Social Information Variable in Contemporary United States Elections." American Journal of Political Science 41: 270-83.

- 1998. "Race and Gender Cues in Low-Information Elections." Political Research Quarterly 51: 895-918.

Morton, Rebecca, and Kenneth C. Williams. 2001. Learning by Voting: Sequential Choices in Presidential Primaries and Other Elections. Ann Arbor: University of Michigan Press.

Mutz, Diana. 1995. "Effects of Horse-Race Coverage on Campaign Coffers: Strategic Contributing in Presidential Primaries." Journal of Politics 57: 1015-42.

_ 1997. "Mechanisms of Momentum: Does Thinking Make it So?" Journal of Politics 59: 104-25.

Norrander, Barbara. 1993. "Nomination Choices: Caucus and Primary Outcomes, 1976-88." American Journal of Political Science 37: 343-64 